\title{
CARA ALAMIAH MENINGKATKAN PRODUKSI ASI PADA IBU NIFAS MENGGUNAKAN MADU
}

\author{
Maftuchah $^{1}$, Siti Nur Umariyah Febriyanti ${ }^{2}$, Fransisca Rosi Novita Rahardian ${ }^{3}$ \\ ${ }^{1,2,3}$ STIKes Karya Husada Semarang \\ E-mail:maftuchah89@gmail.com
}

\begin{abstract}
ABSTRAK
Survey Demografi Kesehatan Indonesia tahun 2012 jumlah ibu yang menyusui baru mencapai 42\%. Data dari UNICEF pada tahun 2015 didapati bayi yang mendapatkan ASI ekslusif sebanyak $32 \%$. Produksi ASI yang berkurang menjadi masalah terutama pada ibu nifas. Hal yang dilakukan untuk menolong ibu yang memiliki produksi ASI kurang adalah mencoba menemukan faktor yang mempengaruhi seperti faktor obat-obatan atau minuman yang aman untuk dikonsumsi oleh ibu menyusui salah satunya adalah madu. Penelitian ini bertujuan untuk mengetahui pengaruh pemberian madu terhadap peningkatan produksi ASI pada ibu nifas. Jenis penelitian ini adalah quasi experiment dengan one group pretest and posttest. Populasi adalah seluruh ibu nifas yang bersalin pada bulan Oktober-November 2017 hari ke-10 yang berjumlah 25 orang dengan teknik sampling accidental sampling. Instrumen dalam penelitian ini adalah gelas ukur dan lembar observasi. Hasil penelitian menunjukkan bahwaProduksi ASI pada Ibu Nifas sebelum pemberian madu rata-rata adalah 799,20 ml per hari dan Produksi ASI pada Ibu Nifas sesudah pemberian madu rata-rata adalah $914 \mathrm{ml}$ perhari. Ada pengaruh pemberian madu terhadap peningkatan produksi ASI pada Ibu Nifas (P-value $=0,000$ ). Diharapkan ibu nifas untuk selalu menyusui bayinya dan mengonsumsi madu masing 2 sendok makan setiap pagi, siang dan malam agar dapat membantu ibu dalam peningkatan produksi ASI.
\end{abstract}

Kata kunci: Air Susu Ibu; Madu; Nifas

\section{HONEY TO INCREASE THE PRODUCTION OF WATER MILK MOTHER AT THE MOTHER POSTPARTUM}

\begin{abstract}
Besides that data from united nation child's fund (UNICEF) in 2015 found babies get the milk mother ekslusif for six month first as much as $32 \%$. Based on the results of preliminary study in RB Citra Insani City Semarang of 45 mothers, 5 mothers who do not give exclusive breastfeeding. To know the influence of giving honey to increase the production of water milk mother at the mother childbirth. The kind of rsearch quasy experiment. The design research one group pretest and posttest. The population in this study were all mothers that maternity in the month of October until November 2017 ten the day which amounts to 25 people. The sampling technique using accidental sampling. The instrument in this study is the observation sheet the production of mother's milk. Analysis of data using univariate analysis and bivariate analysis. The production of mother's milk in puerperal women before the administration of honey the average is 799,20 ml. breast milk production in mother after giving honey the average is $914 \mathrm{ml}$. there is the effect of honey to increase breast milk production in postpartum mothers ( $\mathrm{P}$-value=0,000). It is expected that nursing mothers to consume honey 2 tablespoons, 2 tablespoons, 2 tablespoons in order to assist mothers in increasing milk production.
\end{abstract}

Keywords : Mother's milk; Honey; Postpartum;

Jurnal SMART Kebidanan Sekolah Tinggi Ilmu Kesehatan (STIKes) Karya Husada Semarang www.stikesyahoedsmg.ac.id/ojs/index.php/sjkb 


\section{Pendahuluan}

Faktor nutrisi yang sesuai dalam Air Susu Ibu (ASI) menjamin status gizi bayi baik serta kesakitan anak menurun. Beberapa epidemiologis menyatakan bahwa ASI melindungi bayi dan anak dari penyakit infeksi, misalnya diare dan infeksi saluran pernafasan akut. Kolostrum mengandung zat kekebalan 10-17 kali lebih banyak dari susu matang (matur). Zat kekebalan yang terdapat pada ASI antara lain akan melindungi bayi dari penyakit diare dan menurunkan kemungkinan bayi terkena penyakit infeksi pernafasan dan alergi. ASI adalah susu yang diproduksi secara alamiah dalam tubuh manusia yang terdapat dalam susu ibu. ASI ini hanya ada apabila seorang ibu tengah menyusui dan biasanya untuk konsumsi bayi. ASI diproduksi karena pengaruh hormone prolactin dan oxytocin setelah melahirkan bayi. (Tara : 2016)

Survey Demografi Kesehatan Indonesia tahun 2012 jumlah ibu yang menyusui mencapai 42\%. Di samping itu, data dari United Nation Child's Fund (UNICEF) pada tahun 2015 didapati bayi yang mendapatkan ASI ekslusif selama 6 bulan pertama sebanyak 32\%. Produksi ASI yang berkurang menjadi masalah pada ibu yang baru melahirkan, dan terdapat banyak faktor yang mempengaruhi produksi ASI tersebut. Hal yang dilakukan untuk menolong ibu yang memiliki produksi ASI kurang adalah mencoba menemukan faktor yang mempengaruhi seperti faktor obat-obatan atau minuman yang aman untuk dikonsumsi oleh ibu menyusui salah satunya adalah madu murni. Madu murni adalah kumpulan dari sari bunga. Madu biasanya terdapat dalam sarang lebah yang berbentuk segi enam. Madu memiliki kandungan-kandungan yang sangat banyak dan bermanfaat bagi manusia. Madu memiliki banyak khasiat makanan yang baik bagi kesehatan banyak unsur positif dari kandungan madu tersebut. (WHO : 2016)

Setiap tahun produksi ASI akan berubah volume ASI pada tahun pertama adalah 400-700 ml/24 jam, pada tahun kedua 200-400 ml/24 jam, dan sesudahnya 200-400 ml/24 jam. Jumlah ASI normal diproduksi pada akhir minggu pertama setelah melahirkan adalah $550 \mathrm{ml}$ perhari. Dalam 2-3 minggu, produksi ASI meningkat sampai $800 \mathrm{ml}$ per harinya. Jumlah produksi ASI dapat mencapai 1,5 - 2 liter per harinya, semakin sering ibu menyusui bayinya semakin banyak hormone prolactin dilepaskan, dan semakin banyak produksi ASInya. ASI erat kaitannya dengan makanan yang dikonsumsi masing-masing ibu, ibu membutuhkan setidaknya kalori sebanyak 2500-2700 kkal per harinya untuk memproduksi sekitar $500 \mathrm{ml}$ sampai $800 \mathrm{ml}$ setiap hari. Sementara itu, madu mengandung 304 kkal setiap 
5 cc. Hal ini dapat membantu asupan kalori ibu menyusui dan juga berakibat lancarnya produksi ASI. Madu memiliki kandungan yang sama untuk dapat meningkatkan produksi ASI, fungsi madu terhadap kesehatan ibu menyusui adalah sebagai penambah stamina ibu, sebagai nutrisi ibu menyusui, sebagai anti bodi dalam ASI, bagi bayi dapat menghindari terjadinya pembengkakan jamur dimulut bayi, madu juga bagus untuk lambung dan darah bayi. (Wulandari : 2013)

Data Profil Kesehatan Provinsi Jawa Tengah pada tahun 2014 menunjukkan bahwa cakupan pemberian ASI eksklusif sekitar 61,6 dari total jumlah bayi yaitu 488.495, hanya 181.600 bayi yang mendapatkan ASI eksklusif dan menurun apabila dibandingkan dengan target pencapaian ASI eksklusif tahun 2014 sebesar 60,7\% dari total bayi 340.373 hanya 136.862 yang mendapatkan ASI eksklusif. (Profil Kesehatan Kota Semarang : 2014)

Data dari Dinas Kesehatan Kota (DKK) Semarang tahun 2016 cakupan ASI rendah berada di Puskemas Tlogosari Wetan memiliki cakupan ASI eksklusif rendah, dan studi pendahuluan di Wilayah Kerja Puskesmas Tlogosari Wetan sebanyak 346 bayi laki-laki dan 361 bayi perempuan hanya 7,78\% bayi dengan ASI Eksklusif. (Profil Kesehatan Kota Semarang : 2016)

Berdasarkan hasil studi pendahuluan di Rumah Bersalin Citra Insani Kota Semarang dari $45 \mathrm{ibu}, 5 \mathrm{ibu}$ yang menyatakan bahwa ibu yang bekerja lebih sulit memberikan ASI Eksklusif dari waktu, fasilitas, dan tempat, sedangkan 5 ibu lainnya mengeluh kurangnya produksi ASI yang dihasilkan. Sedangkan menurut hasil wawancara dengan petugas puskemas ditemukan bahwa ibu yang tidak menyusui ASI Eksklusif karena kurang dukungan dan motivasi dari suami dan keluarga, penyebab lain karena ASI yang diproduksi kurang. Ibu-ibu biasanya memberikan bayi mereka dengan susu formula, atau pisang yang ditumbuk, itu karenakan ibu kurang begitu mengetahui dalam usaha pemberian ASI Eksklusif. Banyak cara untuk meningkatkan produksi ASI salah satunya adalah dengan menggunakan madu yang mana secara turun temurun dan menurut peneliti di Jepang dapat mampu meningkatkan jumlah produksi ASI bagi ibu menyusui. Sehingga, berdasarkan hal tersebut peneliti mengambil tema penelitian "Pengaruh Pemberian Madu Terhadap Peningkatan Produksi ASI Pada Ibu Nifas di RB Citra Insani Kota Semarang”. 


\section{Tinjauan Teoritis}

ASI merupakan makanan pertama terbaik bayi yang bersifat alamiah, dan mengandung beberapa zat gizi yang dibutuhkan dalam proses pertumbuhan dan perkembangan bayi. ASI adalah susu yang diproduksi secara alamiah dalam tubuh manusia yang terdapat dalam susu ibu. ASI ini hanya ada apabila seorang ibu tengah menyusui dan biasanya untuk konsumsi bayi. ASI diproduksi karena pengaruh hormone prolactin dan oxytocin setelah kelahiran bayi.ASI pertama yang keluar disebut kolostrum atau jolong dan mengandung banyak immunoglobulin IgA yang baik untuk pertahanan tubuh bayi melawan penyakit. Dalam pemberian ASI tidak dibatasi jumlah takaran. Berikut ini ASI menurut stadium laktasi : Kolostrum, Air Susu Transisi, Matur Jumlah produksi ASI ibu nifas dapat dipengaruhi oleh beberapa faktor berikut : Nutrisi ibu, Ketenangan jiwa dan pikiran, Penggunaan alat kontrasepsi, Perawatan payudara, Anatomis payudara, Pola istirahat, Faktor obat-obatan. (Anggraini : 2010)

Madu adalah cairan manis yang dihasilkan oleh lebah madu berasal dari berbagai sumber nectar. Nectar adalah semacam cairan yang dihasilkan oleh kelenjar nectar tumbuhan, kaya akan berbagai bentuk karbohidrat seperti sukrosa, fruktosa dan glukosa, mengandung sedikit senyawa-senyawa pengandung nitrogen, seperti asam-asam amino, amida-amida, asam-asam organic, vitamin-vitamin, senyawa aromatic dan juga mineralmineral. Hasil riset di Jepang dan beberapa Negara lain membuktikan bahwa madu murni mampu memperbanyak keluarnya ASI dan memperbanyak jumlah antibody dalam ASI. Dengan demikian, kekebalan tubuh bayi terhadap penyakit akan bertambah. Oleh karena itu, seorang ibu yang sedang menyusui anaknya disarakan untuk mengkonsumsi madu sebanyak 6 sendok setiap harinya. Khasiat madu juga efektif dalam menghadapi pembengkakan jamur dimulut bayi. Larutan madu dalam air, kemudian diberikan larutan tersebut diatas mulut bayi maka bercak jamur itu hilang.Hal itu mencegah pembentukan jamur di dalamnya selain itu, madu juga bagus bagi lambung dan darahnya. (Guducu :2017)

Setelah proses kelahiran, seorang ibu dihadapkan pada tanggung jawab yang lebih nyata terhadap bayinya untuk memberikan nutrisi terbaik salah satunya adalah ASI. Akan tetapi, kendalanya adalah seringkali ASI tidak keluar atau hanya keluar sedikit. Kendala ini terutama dijumpai pada ibu dengan persalinan pertama atau dengan persalinan Caesar. Meminum madu dapat memperlancar ASI selain madu ada pula beberapa makanan untuk meningkatkan produksi ASI. 
Seorang ibu membutuhkan setidaknya kalori sebanyak 400-500 kkal per harinya untuk memproduksi sekitar $500 \mathrm{ml}$ sampai $800 \mathrm{ml}$ setiap hari. Sementara itu, madu mengandung 304 kkal setiap 5 cc. Setiap tahun produksi ASI akan berubah volume ASI pada tahun pertama adalah 400-700 ml/24 jam, pada tahun kedua 200-400 ml/24 jam, dan sesudahnya 200-400 ml/24 jam. Jumlah ASI normal diproduksi pada akhir minggu pertama setelah melahirkan adalah $550 \mathrm{ml}$ perhari.Dalam 2-3 minggu, produksi ASI meningkat sampai $800 \mathrm{ml}$ perharinya. Jumlah produksi ASI dapat mencapai 1,5-2 liter per harinya, semakin sering ibu menyusui bayinya semakin banyak hormone prolactin dilepaskan, dan semakin banyak produksi ASInya. ASI erat kaitannya dengan makanan yang dikonsumsi masing-masing ibu, ibu membutuhkan setidaknya kalori sebanyak 2500- 2700 kkal perharinya untuk memproduksi sekitar $500 \mathrm{ml}$ sampai $800 \mathrm{ml}$ setiap hari. Sementara itu, madu mengandung 304 kkal setiap 100 gram. (Faisal :2012)

\section{Metode Penelitian}

Jenis penelitian quasi experiment desain penelitian one group pretest and posttest. Populasi dalam penelitian ini adalah seluruh ibu nifas yang bersalin di RB Citra Insani Kota Semarang pada bulan Oktober sampai dengan November 2017 hari ke-10 berjumlah 25 orang. Teknik pengambilan sampel menggunakan pendekatan secara accidental sampling. Pemberian madu pada ibu nifas diberikan selama 10 hari dimulai dari nifas hari ke-10 s/d hari ke19 dengan jumlah 2 sendok makan setiap pagi, siang dan malam. Madu yang digunakan adalah madu murni khusus untuk ibu menyusui. Data tentang produksi ASI didapat dari responden langsung dan dari lembar observasi. Alat yang digunakan gelas ukur, tangan ibu, dan lembar observasi. Variabel yang diukur produksi ASI.Analisis bivariat dilakukan dengan terlebih dahulu melakukan uji normalitas menggunakan Saphiro Wilk, dilanjutkan dengan uji Wilcoxon ( karena data tidak normal). 


\section{Hasil Penelitian}

\section{Pengaruh Pemberian Madu Terhadap Peningkatan Produksi ASI}

Tabel 1 Pengaruh Pemberian Madu Terhadap Peningkatan Produski ASI Di RB Citra Insani Kota Semarang Tahun 2017

\begin{tabular}{llllcccc}
\hline \multicolumn{1}{c}{ Variabel } & & N & Mean & SD & Min & Max & P-Value \\
\hline $\begin{array}{l}\text { Produksi ASI pada Ibu Nifas } \\
\text { sebelum pemberian madu }\end{array}$ & 25 & 799,20 & 42,024 & 700 & 900 & \\
$\begin{array}{l}\text { Produksi ASI pada ibu nifas } \\
\text { sesudah pemberiaan madu }\end{array}$ & 25 & 914 & 95,219 & 800 & 1200 & 0,000 \\
\hline
\end{tabular}

Hasil penelitian dapat diketahui bahwa Produksi ASI pada Ibu Nifas sebelum pemberian madu rata-rata adalah 799,20 ml dengan standar deviasi 42,024 ml. Produksi ASI pada Ibu Nifas sebelum pemberian madu paling rendah adalah $700 \mathrm{ml}$ dan tertinggi adalah $900 \mathrm{ml}$. Dan dapat diketahui bahwa Produksi ASI pada Ibu Nifas sesudah pemberian madu ratarata adalah $914 \mathrm{ml}$ dengan standar deviasi 95,219 ml. Produksi ASI pada Ibu Nifas sesudah pemberian madu paling rendah adalah $800 \mathrm{ml}$ dan tertinggi adalah $1200 \mathrm{ml}$. Penelitian ini terlebih dahulu melakukan uji kenormalan data menggunakan saphiro wilk (karena responden di bawah 50 orang) didapatkan p-value sebelum pemberian madu 0,001 atau < 0,05 dan p-value sesudah pemberian madu 0,002 atau $<0,05$ kedua data tidak berdistribusi normal maka uji yang digunakan adalah wilcoxon dengan hasil yang didapatkan p-value $0,000<0,05$. Maka dapat disimpulkan bahwa Ha diterima, sehingga ada pengaruh pemberian madu terhadap peningkatan produksi ASI.

\section{Pembahasan}

Hasil penelitian dapat disimpulkan bahwa terdapat peningkatan produksi ASI pada ibu nifas setelah diberikan madu selama 10 hari dengan jumlah 2 sendok setiap pagi, siang dan malam peningkatan produki ASI sekitar $100 \mathrm{ml}$, kenaikan pada produksi ASI tersebut normal antara 50-100 ml. Hal ini disebabkan karena responden yang setuju dan patuh dalam mengkonsumsi madu. Produksi ASI semakin efektif dan terus menerus meningkat pada hari ke 10 dan seterusnya, tanpa mengkonsumsi madu dengan angka normal $800 \mathrm{ml}$, produksi ASI yang dihasilkan setelah pemberian madu adalah $914 \mathrm{ml}$ terjadi kenaikan yang normal yaitu sekitar 100 ml, Kenaikan pada produksi ASI tersebut normal antara 50-100 ml. 
Seorang ibu membutuhkan setidaknya kalori sebanyak 400- 500 kkal perharinya untuk memproduksi sekitar $500 \mathrm{ml}$ sampai $800 \mathrm{ml}$ setiap hari. Sementara itu, madu mengandung 304 kkal setiap 5 cc. Setiap tahun produksi ASI akan berubah volume ASI pada tahun pertama adalah 400-700 ml/24 jam, pada tahun kedua 200-400 ml/24 jam, dan sesudahnya 200-400 ml/24 jam. Jumlah ASI normal diproduksi pada akhir minggu pertama setelah melahirkan adalah $550 \mathrm{ml}$ perhari. Dalam 2-3 minggu, produksi ASI meningkat sampai 800 ml perharinya. Jumlah produksi ASI dapat mencapai 1,5-2 liter perharinya, semakin sering ibu menyusui bayinya semakin banyak hormone prolactin dilepaskan, dan semakin banyak produksi ASInya.

Pengeluaran ASI ini terjadi karena sel otot halus di sekitar kelenjar payudara mengerut sehingga memeras ASI untuk keluar. ASI dapat keluar dari payudara akibat adanya otot-otot yang mengkerut yang dapat distimulasi oleh suatu hormon yang dinamakan oksitoksin. Refleks oksitosin lebih rumit dibanding refleks prolaktin. Pikiran, perasaan dan sensasi seorang ibu akan sangat mempengaruhi refleks ini terutama pada pengeluaran hormon endorphin. Perasaan ibu dapat meningkatkan dan juga menghambat pengeluaran endorphin yang menghasilkan hormon oksitosin. Oksitosin memacu sel-sel myoepithel yang mengelilingi alveoli dan duktuli untuk berkontraksi, sehingga mengalirkan ASI dari alveoli ke duktuli menuju sinus dan puting untuk dihisap oleh bayi. (Kementrian Kesehatan RI : 2014)

Sering kali saat sudah terproduksi ASI tetap tidak dapat dikeluarkan akibat adanya sumbatan maupun kurangnya rangsangan pada otot polos untuk berkontraksi, dengan adanya pemijatan langsung pada payudara maka aliran ASI dalam payudara akan lancar dan menyebabkan rangsangan pada otot halus di kelenjar payudara dapat mengeluarkan dan memproduksi ASI dalam jumlah yang banyak untuk memenuhi kebutuhan nutrisi bayi baru lahir. (Ambarwati:2009)

Menurut penelitian yang dilakukan di negara Jepang membuktikan bahwa madu murni mampu memperbanyak keluarnya ASI dan memperbanyak jumlah antibody dalam ASI. Dengan demikian, kekebalan tubuh bayi terhadap penyakit akan bertambah. Oleh karena itu, seorang ibu yang sedang menyusui anaknya disarankan untuk mengkonsumsi madu sebanyak 6 sendok setiap harinya. Khasiat madu juga efektif dalam menghadapi pembengkakan jamur dimulut bayi. Larutan madu dalam air, kemudian diberikan larutan tersebut di atas mulut bayi maka bercak jamur itu hilang. Hal itu mencegah pembentukan jamur di dalamnya, selain itu madu juga bagus bagi lambung dan darahnya. Madu murni adalah kumpulan dari sari bunga, cairan manis yang dihasilkan oleh lebah madu berasal dari berbagai sumber nectar. Madu 
yang telah dimasak mengandung fruktosa $41,0 \%$, glukosa $35,0 \%$, sukrosa $1,9 \%$, desktrin 1,5 $\%$, mineral 0,2 \%, air $17 \%$, dan zat-zat lain asam amino sebanyak 3,5\%. (Faisal:2012)

Seorang ibu membutuhkan setidaknya kalori sebanyak 400-500 kkal per harinya untuk memproduksi sekitar $500 \mathrm{ml}$ sampai $800 \mathrm{ml}$ setiap hari. Sementara itu, madu mengandung 304 kkal setiap 5 cc. Setiap tahun produksi ASI akan berubah volume ASI pada tahun pertama adalah 400-700 ml/24 jam, pada tahun kedua 200-400 ml/24 jam, dan sesudahnya 200-400 ml/24 jam. Jumlah ASI normal diproduksi pada akhir minggu pertama setelah melahirkan adalah $550 \mathrm{ml}$ perhari. Dalam 2-3 minggu, produksi ASI meningkat sampai 800 ml perharinya. Jumlah produksi ASI dapat mencapai 1,5-2 liter per harinya, semakin sering ibu menyusui bayinya semakin banyak hormone prolactin dilepaskan, dan semakin banyak produksi ASInya. ASI erat kaitannya dengan makanan yang dikonsumsi masing-masing ibu. Ibu menyusui membutuhkan setidaknya kalori sebanyak 2500- 2700 kkal per harinya untuk memproduksi sekitar $500 \mathrm{ml}$ sampai $800 \mathrm{ml}$ setiap hari. Sementara itu, madu mengandung 304 kkal setiap 100 gram.Hal ini tentu sangat membantu kebutuhan asupan kalori ibu menyusui dan juga berakibat lancarnya produksi ASI. (Faisal:2012)

Setelah proses kelahiran, seorang ibu dihadapkan pada tanggung jawab yang lebih nyata terhadap bayinya untuk memberikan nutrisi terbaik salah satunya adalah ASI. Akan tetapi, kendalanya adalah seringkali ASI tidak keluar atau hanya keluar sedikit. Kendala ini terutama dijumpai pada ibu dengan persalinan pertama atau dengan persalinan Caesar. (Cholid:2011)

Pada produksi ASI ibu nifas biasanya akan mengalami penurunan atau pun peningkatan pada produksi ASI nya karena beberapa faktor. Faktor-faktor yang mempengaruhi dalam peningkatan atau penurunan pada produksi ASI tersebut adalah bisa dari psikologi ibu, nutrisi ibu (makanan, minuman, sayur, buah-buahan), pola istirahat (jika siang ibu istirahat 1-2 jam malam ibu bisa tidur 7-8 jam), faktor isapan anak (semakin sering menyusui maka semakin banyak produksi ASI yang dihasilkan). Menurut hasil tabulasi pada tabel, terdapat 2 ibu yang mengalami penurunan pada produksi ASI nya kemungkinan karena faktor psikologis ibu, pola istirahat ibu yang kurang karena anaknya rewel dan sebagainya, faktor nutrisi ibu dari makanan atau minuman, bisa juga terjadi pada isapan anak yang kurang adekuat. Ibu nifas yang produksi ASI meningkat terdapat $20 \mathrm{ibu}$ yang mengalami kenaikan pada produksi ASI nya faktor yang terjadi karena faktor nutrisi ibu yang baik (makanan, minuman, sayur, buah-buhan) ibu sering mengkonsumsi madu sehingga dapat membantu ibu dalam meningkatkan produksi ASInya, pola istirahat ibu yang baik, faktor psikologis ibu, 
ketenangan jiwa dan pikiran ibu, faktor isapan anak yang baik. Terdapat 3 ibu yang produksi ASInya menetap tidak turun dan naik. (Cholid:2012)

Penelitian yang dilakukan oleh Siregar (2014) menunjukkan bahwa pemberian ASI eksklusif dipengaruhi oleh berbagai faktor antara lain ASI tidak segera keluar setelah melahirkan atau kecukupan ASI kurang, kesulitan bayi dalam menghisap, keadaan puting susu ibu yang tidak menunjang, ibu bekerja, dan pengaruh atau promosi pengganti ASI. (Siregar : 2014)

\section{Kesimpulan}

Madu yang diminum selama 10 hari dengan jumlah 2 sendok setiap pagi, siang dan malam dapat meningkatkan produksi Air Susu Ibu (ASI) pada ibu nifas di RB Citra Insani Kota Semarang.

\section{Saran}

Pihak Rumah Bersalin CI Kota Semarang diharapkan dapat mempromosikan madu kepada ibu nifas sebagai salah satu upaya yang mendukung peningkatan produksi ASI. Diharapkan ibu menyusui agar mengonsumsi madu 2 sendok setiap pagi, siang dan malam selama 10 hari agar produksi ASI meningkat dengan tetap menjaga nutrisi, kesehatan mental ibu, kecukupan istirahat, dan pemberian ASI secara on demand.

\section{Daftar Pustaka}

Ambarwati.(2009). Asuhan Kebidanan Nifas. Yogyakarta : Mitra Cendekia Press.

Anggraini, Y. (2010). Asuhan Kebidanan Masa Nifas. Yogyakarta : Pustaka Rihana.

Cholid, S. (2011). Pengaruh Pemberian Madu Pada Diare Akut, Vol.12, No.5, Februari 2011.

Desytrilistyoati.5 Manfaat Madu Untuk Ibu Menyusui.Menyusui.com. 20 Mei 2017.http://.ehamil.co.id/pasca- hamil/menyusui/manfaat-madu-untuk-ibu-menyusui (15 Agustus 2016).

Faisal. (2012). Madu dan Khasiatnya. Yogyakarta: Diandra Pustaka Indonesia.

Guducu, F. (2017). Milk With Honey Heals After Tonsillectomy; Bleeding, Pain And Wound Healing Are In A Better Condition : An Experimental Study With Control Group. Vol. 10 Page 4332017.

Kementerian Kesehatan RI (2014). Diakses pada tanggal 4 Mei 2017 pukul 7:37 PM. 
Profil Kesehatan Kota Semarang. (2014). http://www.depkes.go.id diakses pada tanggal 9 Mei 2017.

Siregar. (2014). Pemberian ASI Ekslusif Melalui Berbagai Faktor.

Sugiyono. (2013). Metodologi Penelitian Kuantitatif Kualitatif. Alfabeta. Bandung

Tara, A. (2016). Efektivitas Ekstrasi Alkaloid dan sterol Daun Katuk Terhadap Produksi ASI, Majority,Vol.5, no. 1 hal 177-121, Februari 2016.

WHO. (2016). http://www.depkes.go.id. Diakses pada tanggal 29 April 2017 pukul 12.26 WIB.

Widyasih, H. (2009). Inisiasi Menyusu Dini. Yogyakarta : Fitramaya.

Wulandari, M. (2013). Cara Menghitung Volume ASI Dan Zat Gizinya.http://caramenghitung-volume-ASI-dan-zat-gizinya. Diakses tanggal 23-6-2017 jam 19.35 WIB 